\title{
Stress-induced hashitoxicosis: case report and relative HLA serotype and genotype
}

\author{
(iD) Roberto Vita ${ }^{1}$ \\ (D) Valeria Cernaro ${ }^{2}$ \\ Salvatore Benvenga $a^{1,3,4}$
}

\begin{abstract}
1. Endocrinology, Department of Clinical and Experimental Medicine, University of Messina, Messina, Italy 2. Unit of Nephrology and Dialysis, Department of Clinical and Experimental Medicine, University hospital, AOU Policlinico G. Martino, Messina, Italy 3. Master Program on Childhood, Adolescent and Women's Endocrine Health, University of Messina, Messina, Italy 4. Interdepartmental Program of Molecular \& Clinical Endocrinology, and Women's Endocrine Health, University hospital Policlinico G. Martino, Messina, Italy This work is associated with the University of Messina.
\end{abstract}

http://dx.doi.org/10.1590/1806-9282.65.6.830

\section{SUMMARY}

OBJECTIVE. Even though stress has been long known as a provocative factor for Graves' disease, its relationship with Hashimoto's thyroiditis is more controversial. Studies on this topic are scanty. This paper aims to report a case of stress-induced Hashitoxicosis.

RESULTS. Here we report a case of Hashitoxicosis induced by a psychological stressful event in a 28-year-old woman with Hashimoto's thyroiditis. She had remained stably euthyroid for 12 years. She was first observed in April 2016, while euthyroid. She came back after 11 months because of fatigue and palpitations, in the absence of neck pain. Thyroid function tests revealed moderate thyrotoxicosis (undetectable TSH; FT4 36.94 pmol/L, normal values 9.0-24.46; FT3 13.50 pmol/L, normal values 3.07-6.14) with negative TSH-receptor antibodies. In the previous three months, she had experienced a psychological stressful event. Inflammatory markers were negative, and the white cell count was normal. Thyroid ultrasound revealed a modest increase in vascularization. Transient subclinical hypothyroidism ensued after seven weeks and spontaneously recovered. On the last visit, the patient was still on euthyroidism. (TSH $1.01 \mathrm{mU} / \mathrm{L}$; FT4 $9.22 \mathrm{pmol} / \mathrm{L}$; FT3 $3.98 \mathrm{pmol} / \mathrm{L}$ ). We also performed HLA serotyping and genotyping.

CONCLUSION. This case demonstrates that, similarly to Graves' disease, Hashitoxicosis can also be triggered by stressful life events. KEYWORDS: Hashimoto Disease. Thyrotoxicosis. Hyperthyroidism. Hypothyroidism.

\section{INTRODUCTION}

Autoimmune thyroid diseases develop in genetically predisposed individuals who are exposed to certain environmental factors that are capable to trigger an immune response against self-antigens. ${ }^{1}$ Endogenous predisposition includes susceptibility genes, such as thyroid-specific (Tg, TSH receptor) or immune-modulating genes (HLA, CTLA-4, CD24, CD40, FOXP3), ${ }^{2}$. Exogenous or environmental triggers include drugs, pollutants, infections, physical and psychological stress. ${ }^{1,3}$ Particularly, we have recently found that physical, infectious, and psychological stressful events, alone or combined, may precede the onset and the recurrences of Graves' disease. ${ }^{4-6}$

We report here a patient with Hashimoto's thyroiditis, in whom stable euthyroidism was disrupted by a psychologically stressful event with transient thyrotoxicosis followed by transient hypothyroidism. 


\section{CASE}

A woman was diagnosed with Hashimoto's thyroiditis at 17 years of age. She had remained stably euthyroid over the subsequent 12 years (Fig.1); therefore, she had been never treated with levothyroxine. At first observation in April 2016, the patient was 28-year-old and euthyroid (TSH $1.20 \mathrm{mU} / \mathrm{L}$, normal values $0.25-4.0 ;$ FT4 $11.04 \mathrm{pmol} / \mathrm{L}$, normal values 9.0-24.46; thyroperoxidase antibodies [TPOAb] 398 $\mathrm{U} / \mathrm{ml})$. Ultrasound revealed a normal sized $(15 \mathrm{ml})$ slightly hypoechoic thyroid, with diffusely inhomogeneous echo pattern and pseudonodules; vascularization was modestly and diffusely increased. After eleven months, the patient wcame back because of moderate fatigue and palpitations. Suspecting thyrotoxicosis, we inquired about possible triggers. The patient admitted that, over the past three months, she had been distressed because she failed to graduate in her current session. Physical examination showed normal blood pressure $(120 / 80 \mathrm{mmHg})$ with high-normal pulses (88 bpm). Body weight was unchanged as compared with the previous visit one year earlier (56 kg). Thyroid function tests were con- sistent with the diagnosis of Hashitoxicosis, in that they confirmed our suspicion, since free thyroid hormones levels were 1.5 to 2 -fold over the normal upper limit (FT4 $36.94 \mathrm{pmol} / \mathrm{L}$; FT3 $13.50 \mathrm{pmol} / \mathrm{L}$, normal values 3.07-6.14), and TSH was suppressed (Fig.1). Serum thyroglobulin antibodies (TgAb) were undetectable, while TPOAb were positive at levels threefold higher compared to the previous year $(1,242.0$ vs. $398 \mathrm{U} / \mathrm{ml})$. Serum TSH-receptor antibodies were undetectable. Routine blood chemistry, including hemogram and inflammatory markers (erythrocyte sedimentation rate, C-reactive protein, and fibrinogen) was unremarkable. She was not taking any medication other than oral contraceptive pills. Thyroid ultrasound was unchanged compared to one year earlier. Thyroid hormones decreased over the following four weeks, and only FT3 remained slightly over the normal upper limit $(6.6 \mathrm{pmol} / \mathrm{L})$. In parallel, symptoms improved. However, TSH jumped to $6.71 \mathrm{mU} / \mathrm{L}$ over the following three weeks, and FT4 dropped close to the lower normal limit $(9.10 \mathrm{pmol} / \mathrm{L})$ (Fig.1). Body weight increased by two kilograms (58 $\mathrm{kg})$. Since the patient did not complain about any

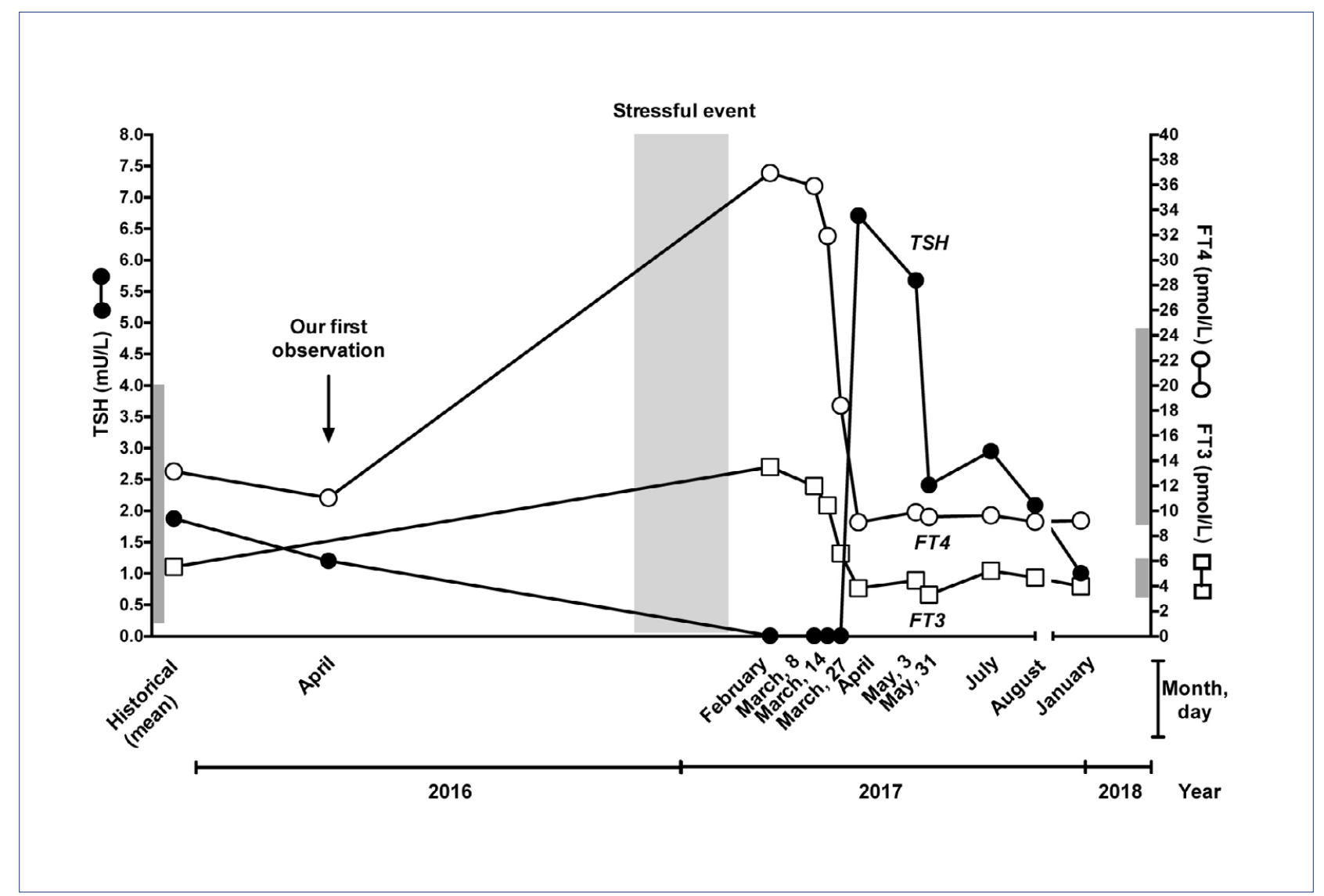

FIGURE 1: SERUM VARIATIONS OF TSH, FT4, AND FT3 OVER TIME. THE INTERVAL IN WHICH THE STRESSFUL EVENT OCCURRED IS SHADOWED. NORMAL VALUES OF TSH, FT4, AND FT3 ARE GREY-BOXED (TSH 0.25-4.0 MU/L; FT4 9.0-24.46 PMOL/L; FT3 3.07-6.14 PMOL/L). 
symptom and was not seeking pregnancy, we elected not to treat her but watchfully wait. TSH, FT4, and FT3 normalized over the following four weeks $(2.41 \mathrm{mU} / \mathrm{L}, 9.52 \mathrm{pmol} / \mathrm{L}$ and $3.32 \mathrm{pmol} / \mathrm{L}$, respectively) and remained stable thereafter (Fig.1). Patient's HLA serotype was HLA A4/13, C7/16, DR4/13-52-53, DQ4/6. We also performed HLA genotyping, which was $\mathrm{A}^{*} 04 / 13, \mathrm{C}^{*} 07 / 16$, DRB1*04/13, DQB1*04/06, DQA1*0303/0103.

\section{DISCUSSION}

Even though stress has been long known as a provocative factor for Graves' disease,${ }^{4-7}$ its relationship with Hashimoto's thyroiditis is more controversial. ${ }^{7,8}$ Studies on this topic are scanty. Either a stressful event or pregnancy has been recognized in $6 \%$ or $10 \%$ of 95 patients with autoimmune thyroiditis, in contrast with $11 \%$ or $25 \%$ of 98 patients with Graves' disease, respectively. ${ }^{9}$ In a prospective study on a Dutch cohort, stressful events were associated neither to de novo occurrence of TPOAb nor to autoimmune hypothyroidism. ${ }^{10}$ Similarly, in another study by the same group, the authors did not find any correlation between stress and positive TPOAb in euthyroid women. ${ }^{11}$ Finally, the thyroid antibody status was shown to be independent of stress in the postpartum period. ${ }^{12}$

The long interval between the beginning of the autoimmune response and the onset of Hashimoto's thyroiditis makes it difficult to assess the role of stress in triggering the disease. ${ }^{13}$ Hashimoto's thyroiditis may present with euthyroidism, hypothyroidism or, rarely, with thyrotoxicosis (Hashitoxicosis). At our institution, half of the patients present normal thyroid function, while the others are almost exclusively hypothyroid. ${ }^{14}$ Within hypothyroidism, the rate of subclinical thyroid failure (i.e. high TSH and normal FT4) has been steadily increasing over the last decades, as opposed to overt failure (i.e. high TSH and low FT4). ${ }^{14}$ The occurrence of Hashitoxicosis is a rare event $(<$ $5 \%$ ), and its prevalence has remained stable over the last decades. ${ }^{14}$. Hashitoxicosis, which was first described by Fatourechi et al. ${ }^{15}$ in 1971, is five-fold more frequent in women than in men, with a peak between the age of 40 and 60 years. It is caused by the inflammation-mediated destruction of thyroid follicles with subsequent leakage of preformed thyroid hormones in the circulation. ${ }^{16}$ Hashitoxi- cosis is transient and lasts from 3 to 24 months, as it evolves into either hypothyroidism or euthyroidism. ${ }^{15}$

In the case reported here, the patient had remained euthyroid for more than ten years. As confirmed by relatives, during the three months preceding thyrotoxicosis she had been distressed because of failure to achieve what she considered a fundamental personal goal, namely to graduate on time. Noteworthy, she could not recall stressful events occurring prior to the diagnosis of Hashimoto's thyroiditis.

Differential diagnosis of Hashitoxicosis includes other causes of thyrotoxicosis. Negative TSH-receptor antibodies, the absence of "thyroid inferno" at the ultrasound, the absence of ophthalmopathy, and the mildness of symptoms rendered Graves' disease to be unlikely. Finally, the absence of a recent viral infection of the upper respiratory tract, the absence of neck pain, normal white cell count and negative inflammatory markers allowed us to exclude subacute thyroiditis.

We also evaluated the patient's HLA status. HLA molecules are involved in the immune response by participating in the presentation of endogenous antigens to CD8+ lymphocytes (HLA class I) and exogenous antigens to CD4+ lymphocytes (HLA class II). Carrying certain HLA antigens is considered a risk for the development of autoimmune diseases. ${ }^{17}$ Hashimoto's thyroiditis and Graves' disease share, at least in part, common HLA antigens, such as DR3. We also found HLA Cw7 (C*07) and HLA DR4 $\left(\mathrm{DRB1}^{*} \mathrm{O} 4\right)$ in our patient. Interestingly, these haplotypes were among the most frequent in patients with stress-related Graves' disease, in whom they were more common than in healthy controls (Cw7 $66.1 \%$ vs. $32.3 \%, \mathrm{P}<0.0001 ; \mathrm{C}^{*} 0765 \%$ vs. $32.3 \%$, P 0.006; DR4 30.8\% vs. 10.8\%, P 0.001; DRB1*04 $35 \%$ vs. $10.8 \%, \mathrm{P}=0.01) .^{5}$ Also, Hashimoto's thyroiditis has been demonstrated to be strongly associated with HLA DR4 allele (DRB1*04-DQB1*03DQA1 $\left.{ }^{*} 03\right) \cdot{ }^{17-19}$ In our case, the patient carried both DRB1*04 and DQA1*03.

\section{CONCLUSIONS}

This case demonstrates that Hashitoxicosis can be elicited by stressors, similarly to Graves' disease. Further studies are warranted to assess genetic markers of susceptibility for stress-induced Hashitoxicosis. 


\section{RESUMO}

OBJETIVO. Mesmo que o estresse seja conhecido há muito tempo como um fator provocativo para a doença de Graves, sua relação com a tireoidite de Hashimoto é mais controversa. Estudos sobre esse tema são escassos. O objetivo deste artigo é relatar um caso de Hashitoxicose induzida por estresse.

RESULTADOS. Aqui nós relatamos um caso de Hashitoxicose induzido por um evento psicológico estressante em uma mulher de 28 anos com tireoidite de Hashimoto. Ela permaneceu estável eutireoidiana por 12 anos. Ela veio a nossa observação pela primeira vez em abril de 2016, enquanto eutireoidiana. Voltou após 11 meses por causa de fadiga e palpitações, na ausência de dor no pescoço. Testes de função tireoidiana revelaram uma tireotoxicose moderada (TSH indetectável; T4F 36,94 pmol/L, valores normais 9,0-24,46; FT3 13,50 pmol/L, valores normais 3,07-6,14) com anticorpos negativos para o receptor de TSH. Nos últimos três meses ela experimentou um evento psicológico estressante. Os marcadores inflamatórios foram negativos e a contagem de leucócitos foi normal. A ultrassonografia da tireoide revelou um aumento modesto da vascularização. Hipotireoidismo subclínico transitório ocorreu após sete semanas e se recuperou espontaneamente. Na última visita, a paciente ainda estava em eutireoidismo. (TSH 1,01 mU/L; FT4 9,22 pmol/L; FT3 3,98 pmol/L). Também realizamos a sorotipagem e a genotipização do HLA.

CONCLUSÃo. Este caso demonstra que, similarmente à doença de Graves, também a Hashitoxicose pode ser desencadeada por eventos estressantes da vida.

palaVRas-ChaVe: Doença de Hashimoto. Tireotoxicose. Hipertireoidismo. Hipotireoidismo.

\section{REFERENCES}

1. Guarneri F, Benvenga S. Environmental factors and genetic background that interact to cause autoimmune thyroid disease. Curr Opin Endocrinol Diabetes Obes. 2007;14(5):398-409.

2. Lee HJ, Li CW, Hammerstad SS, Stefan M, Tomer Y. Immunogenetics of autoimmune thyroid diseases: a comprehensive review. I Autoimmun. 2015;64:82-90.

3. Benvenga S, Guarneri F. Molecular mimicry and autoimmune thyroid disease. Rev Endocr Metab Disord. 2016;17(4):485-98.

4. Vita R, Lapa D, Trimarchi F, Benvenga S. Stress triggers the onset and the recurrences of hyperthyroidism in patients with Graves' disease. Endocrine. 2015;48(1):254-63.

5. Vita R, Lapa D, Trimarchi F, Vita G, Fallahi P, Antonelli A, et al. Certain HLA alleles are associated with stress-triggered Graves' disease and influence its course. Endocrine. 2017:55(1):93-100.

6. Vita R, Lapa D, Vita G, Trimarchi F, Benvenga S. A patient with stress-related onset and exacerbations of Graves disease. Nat Clin Pract Endocrinol Metab. 2009;5(1):55-61.

7. Effraimidis G, Wiersinga WM. Mechanisms in endocrinology: autoimmune thyroid disease: old and new players. Eur J Endocrinol. 2014;170(6):R241-52.

8. Bagnasco M, Bossert I, Pesce G. Stress and autoimmune thyroid diseases. Neuroimmunomodulation. 2006;13(5-6):309-17.

9. Martin-du Pan RC. Triggering role of emotional stress and childbirth Unexpected occurrence of Graves' disease compared to 96 cases of Hashimoto thyroiditis and 97 cases of thyroid nodules. Ann Endocrinol (Paris). 1998;59(2):107-12

10. Effraimidis G, Tijssen JG, Brosschot JF, Wiersinga WM. Involvement of stress in the pathogenesis of autoimmune thyroid disease: a prospective study. Psychoneuroendocrinology. 2012;37(8):1191-8.

11. Strieder TG, Prummel MF, Tijssen JG, Brosschot JF, Wiersinga WM. Stress is not associated with thyroid peroxidase autoantibodies in euthyroid women. Brain Behav Immun. 2005;19(3):203-6.

12. Oretti RG, Harris B, Lazarus JH, Parkes AB, Crownshaw T. Is there an association between life events, postnatal depression and thyroid dysfunction in thyroid antibody positive women? Int J Soc Psychiatry. 2003;49(1):70-6.

13. Tsatsoulis $A$. The role of stress in the clinical expression of thyroid autoimmunity. Ann N Y Acad Sci. 2006;1088:382-95.

14. Benvenga $S$, Trimarchi F. Changed presentation of Hashimoto's thyroiditis in North-Eastern Sicily and Calabria (Southern Italy) based on a 31-year experience. Thyroid. 2008;18(4):429-41.

15. Fatourechi V, McConahey WM, Woolner LB. Hyperthyroidism associated with histologic Hashimoto's thyroiditis. Mayo Clin Proc. 1971;46(10):682-9.

16. Caturegli $P$, De Remigis $A$, Rose NR. Hashimoto thyroiditis: clinical and diagnostic criteria. Autoimmun Rev. 2014;13(4-5):391-7.

17. Zeitlin AA, Heward JM, Newby PR, Carr-Smith JD, Franklyn JA, Gough SC, et al. Analysis of HLA class II genes in Hashimoto's thyroiditis reveals differences compared to Graves' disease. Genes Immun. 2008;9(4):358-63.

18. Wan XL, Kimura A, Dong RP, Honda K, Tamai H, Sasazuki T. HLA-A and -DRB4 genes in controlling the susceptibility to Hashimoto's thyroiditis. Hum Immunol. 1995;42(2):131-6.

19. Petrone A, Giorgi G, Mesturino CA, Capizzi M, Cascino I, Nistico L, et al. Association of DRB1 ${ }^{*} 04-D Q B 1^{*} 0301$ haplotype and lack of association of two polymorphic sites at CTLA-4 gene with Hashimoto's thyroiditis in an Italian population. Thyroid. 2001;11(2):171-5. 